\title{
Physicochemical and Sensory Evaluation of Dhakki Dates Candy
}

\section{Zeeshan $\mathbf{M}^{1 *}$, Saleem SA ${ }^{1}$, Ayub $\mathbf{M}^{2}$, Shah $\mathbf{M}^{2}$ and Jan $\mathbf{Z}^{2}$}

${ }^{1}$ Food Technology Section, Agricultural Research Institute, D.I. Khan, K.P, Pakistan

${ }^{2}$ University of Agriculture, Peshawar, K.P, Pakistan

\begin{abstract}
The experiment was conducted to develop candy from Dhakki dates picked at Khalal stage. Physicochemical and sensory characteristics like moisture, $\mathrm{pH}$, TSS, color, flavor, texture and overall acceptability were studied for total period of six months. Candy was prepared from 5 different sugar concentrations, i.e., T0 (control), T1 (20\%), T2 (40\%), T3 $(60 \%)$, and T4 $(70 \%)$. Among them, best treatment was identified on the basis of overall acceptability. Candy prepared from T3 $(60 \%)$ proved to be best but the candy prepared from T2 $(40 \%)$ was equally good. The least acceptable was the candy of T1 followed by T4. Sensorial properties, moisture and $\mathrm{pH}$ decreased while TSS increased during six months of storage. Candy packed in HDPE bags can be kept safely up to six months.
\end{abstract}

Keywords: Physicochemical; Sensory properties; Sucrose; Khalal stage

\section{Introduction}

Date palm (Phoenix dactylifera L.) is an important fruit crop known from centauries as a high-energy food and desert. The nutritional value of date is high since it contains sugar, minerals and vitamins [1]. Sugars contain more than $70 \%$ of dry weight and are an important nutrient in dates. Dates play an important role in both mental and sexual activities. They also provide protection against age related problems which may be contributed to their high content of antioxidant compounds [2].

Carbohydrates, vitamins and minerals rich dates are good not only for humans but can also be used as a feed supplement for livestocks. (Zohary and Hopf [3]; Al-Shahib and Marshal [4]; Hassan et al. [5]

Asia stands first among region with 60 million date palms mostly grown in Saudi Arabia, Bahrain, Oman, Pakistan, Iran, Iraq and Yemen followed by African region with 32.5 million date palms. Mexico and USA have 600,000 date palms followed by Europe and Australia with 320,000 and 30,000 date palms respectively [6].

Pakistan was the $5^{\text {th }}$ largest date producer with an annual production of $600,000 \mathrm{t}$ in 2012 which may be contributed to the increase in cultivation of area of date palms in 2012 [7]. Many varieties are grown in Pakistan and some cultivars are grown in specific areas, like Dhakki in Dera Ismail Khan, Begum Jhangi in Panjgur and Aseel in Khairpur, all have the capability to compete with the world dates [8].

Among the local varieties in Dera Ismail Khan Dhakki is very popular for its jumbo size and weight with pleasure taste and texture [9]. Consumer demand for Dhakki dates is increasing rapidly in Dera Ismail Khan [10]

But the problem with Dhakki date in Dera Ismail Khan is that, monsoon rains occurs from July to September, which coincide with the date ripening season in the area. Date palm is mainly sensitive to rain from khalal (maturity) to rutab and Tamar (ripening). Rain can easily deteriorate dates within 2 days, at late khalal stage crakes in epicarp can appear even in hours. At early khalal stage, rain does not cause any damage and even may have a beneficial effect by washing dirt and dust [11].

To overcome these problems many studies have been carried out on date palm by-products like date pickles, jams, date syrup, ice creams, chocolates and date paste. (Al-Hooti et al. [12]; Hamad et al. [13]; Khatchadourain et al. [14]
Yousif et al. [15] conducted his research on the possibility of using date paste as a replacer for caramel or sugar paste in preparing candy bars. Processing conditions, nutritive value and organoleptic properties of the prepared date bars as well as their storability were evaluated. The results indicated that the prepared date bars either plain or chocolate coated had good acceptability, possessed a high nutritive value and could be stored for more than 5 months under refrigeration $\left(5^{\circ} \mathrm{C}\right)$ without affecting their qualities.

Candy or confectionary is popular food item. Most of fruit candies available in market are imported. The availability of dates in substantial quantities in Dera Ismail Khan justify their use in various products and processing plain which can be used as a replacer for dates when the season is off.

Therefore, the objectives of the present study were to develop date candy from dhakki variety using different sugar concentration and to assess its quality in order to make the product available through the year, to generate income and improve marketability of the dates in a proper way for the benefits of farmers.

\section{Materials and Methods}

The experiment was conducted in month of August 2016, at Agriculture Research Institute Dera Ismail Khan. Dhakki dates at khalal stage were picked from the orchard of Agriculture Research Institute Dera Ismail khan and brought to laboratory of Food Technology Section.

\section{Preparation of dhakki date candy}

The dates were steeped in $0 \%$ sugar syrup for one day and then syrup was drained and dates were dried. Sugar was added to the syrup until TSS reached $20 \%$ and dates were steeped for $24 \mathrm{hrs}$. After $24 \mathrm{hr}$ 's dates

*Corresponding author: Zeeshan M, Food Technology Section, Agricultura Research Institute, D.I. Khan, K.P, Pakistan, Tel: 03479309105; E-mail zeeshanfst07@gmail.com

Received February 13, 2017; Accepted March 07, 2017; Published March 14 2017

Citation: Zeeshan M, Saleem SA, Ayub M, Shah M, Jan Z (2017) Physicochemica and Sensory Evaluation of Dhakki Dates Candy. J Food Process Technol 8: 663. doi: 10.4172/2157-7110.1000663

Copyright: (c) 2017 Zeeshan M, et al. This is an open-access article distributed under the terms of the Creative Commons Attribution License, which permits unrestricted use, distribution, and reproduction in any medium, provided the original author and source are credited. 


\begin{tabular}{|c|c|c|c|c|c|c|c|c|c|}
\hline \multirow{2}{*}{ Treatment } & \multicolumn{7}{|c|}{ Storage Interval } & \multirow{2}{*}{$\%$ Dec } & \multirow{2}{*}{ Mean } \\
\hline & 0 & 30 & 60 & 90 & 120 & 150 & 180 & & \\
\hline T0 & 16.14 & 15.02 & 14.23 & 13.67 & 13.04 & 12.35 & 12.00 & 25.65 & $13.7 \mathrm{~d}$ \\
\hline T1 & 15.18 & 15.00 & 14.56 & 14.12 & 13.78 & 13.13 & 12.45 & 17.98 & $14 \mathrm{~b}$ \\
\hline T2 & 16.77 & 16.12 & 15.44 & 14.89 & 14.10 & 13.77 & 13.33 & 20.51 & $14.9 a$ \\
\hline T3 & 14.16 & 13.68 & 13.12 & 12.78 & 12.22 & 12.00 & 11.89 & 16.03 & $12.8 \mathrm{e}$ \\
\hline T4 & 14.87 & 14.45 & 14.12 & 13.78 & 13.44 & 13.14 & 12.89 & 13.32 & $13.8 \mathrm{c}$ \\
\hline Mean & $15.4 a$ & $14.8 \mathrm{~b}$ & $14.2 \mathrm{c}$ & $13.8 \mathrm{~d}$ & $13.3 \mathrm{e}$ & $12.8 f$ & $12.5 \mathrm{~g}$ & -- & -- \\
\hline
\end{tabular}

Table 1: Effect of storage period and treatments on (\%) moisture of date candy.

\begin{tabular}{|c|c|c|c|c|c|c|c|c|c|}
\hline \multirow{2}{*}{ Treatment } & \multicolumn{7}{|c|}{ Storage Interval } & \multirow[t]{2}{*}{$\%$ Dec } & \multirow[t]{2}{*}{ Mean } \\
\hline & 0 & 30 & 60 & 90 & 120 & 150 & 180 & & \\
\hline T0 & 5.96 & 5.67 & 5.14 & 4.67 & 4.35 & 4.11 & 4.00 & 32.89 & $4.81 \mathrm{c}$ \\
\hline T1 & 5.46 & 5.35 & 5.13 & 4.97 & 4.66 & 4.37 & 4.14 & 24.13 & $4.84 \mathrm{bc}$ \\
\hline T2 & 5.67 & 5.35 & 5.16 & 4.03 & 3.88 & 3.76 & 3.45 & 39.15 & $4.4 d$ \\
\hline T3 & 5.70 & 5.37 & 5.21 & 5.09 & 4.79 & 4.56 & 4.30 & 24.56 & $5 a$ \\
\hline T4 & 5.40 & 5.26 & 5.08 & 4.91 & 4.76 & 4.49 & 4.28 & 20.74 & $4.83 \mathrm{~b}$ \\
\hline Mean & $5.63 a$ & $5.4 \mathrm{~b}$ & $5.1 \mathrm{c}$ & $4.7 \mathrm{~d}$ & $4.4 \mathrm{e}$ & $4.2 f$ & $4 \mathrm{~g}$ & -- & -- \\
\hline
\end{tabular}

Table 2: Effect of storage period and treatment on $\mathrm{pH}$ of date candy.

\begin{tabular}{|c|c|c|c|c|c|c|c|c|c|}
\hline \multirow{2}{*}{ Treatment } & \multicolumn{7}{|c|}{ Storage Interval } & \% Inc & Mean \\
\cline { 2 - 11 } & $\mathbf{0}$ & $\mathbf{3 0}$ & $\mathbf{6 0}$ & $\mathbf{9 0}$ & $\mathbf{1 2 0}$ & $\mathbf{1 5 0}$ & $\mathbf{1 8 0}$ & & \\
\hline T0 & 45.14 & 45.34 & 45.61 & 45.92 & 46.13 & 46.37 & 46.59 & 3.11 & $47.6 \mathrm{e}$ \\
\hline T1 & 71.12 & 71.79 & 72.36 & 73.12 & 73.79 & 74.37 & 74.97 & 5.14 & $71.7 \mathrm{~d}$ \\
\hline T2 & 72.18 & 73.20 & 73.76 & 74.11 & 74.57 & 74.97 & 75.34 & 4.19 & $73.6 \mathrm{~b}$ \\
\hline T3 & 72.25 & 72.78 & 73.23 & 73.47 & 73.88 & 74.35 & 74.80 & 3.41 & $73.5 \mathrm{c}$ \\
\hline T4 & 73.12 & 73.57 & 73.98 & 74.25 & 74.56 & 74.88 & 75.65 & 3.34 & $74.2 \mathrm{a}$ \\
\hline Mean & $66.6 \mathrm{~g}$ & $67.2 \mathrm{f}$ & $67.7 \mathrm{e}$ & $68.2 \mathrm{~d}$ & $68.5 \mathrm{c}$ & $69 \mathrm{~b}$ & $69.5 \mathrm{a}$ & & \\
\hline a-9 Means followed by different letters are significant (PS0.05). & & \\
\hline
\end{tabular}

Table 3: Effect of storage period and treatments on TSS of date candy.

\begin{tabular}{|c|c|c|c|c|c|c|c|c|c|}
\hline \multirow{2}{*}{ Treatment } & \multicolumn{7}{|c|}{ Storage Interval } \\
\cline { 2 - 11 } & $\mathbf{0}$ & $\mathbf{3 0}$ & $\mathbf{6 0}$ & $\mathbf{9 0}$ & $\mathbf{1 2 0}$ & $\mathbf{1 5 0}$ & $\mathbf{1 8 0}$ & \% Dec & Mean \\
\hline T0 & 8 & 5 & 2 & 1 & 1 & 1 & 1 & 87.50 & $2.7 \mathrm{c}$ \\
\hline T1 & 9 & 8.7 & 8.5 & 8 & 7.3 & 6 & 5 & 44.44 & $7.5 \mathrm{~b}$ \\
\hline T2 & 9 & 8.8 & 8.4 & 8 & 7.5 & 7.2 & 7 & 22.22 & $7.9 \mathrm{a}$ \\
\hline T3 & 9 & 8.5 & 8.2 & 8 & 7.7 & 7.5 & 7.1 & 21.11 & $8.0 \mathrm{a}$ \\
\hline T4 & 8.6 & 8.2 & 7.8 & 7.4 & 7 & 6.6 & 6 & 30.23 & $7.3 \mathrm{~b}$ \\
\hline Mean & $8.7 \mathrm{a}$ & $7.8 \mathrm{~b}$ & $6.9 \mathrm{c}$ & $6.4 \mathrm{~d}$ & $6.1 \mathrm{e}$ & $5.6 \mathrm{f}$ & $5.2 \mathrm{~g}$ & -- & -- \\
\hline
\end{tabular}

a-g Means followed by different letters are significant $(P \leq 0.05)$.

Table 4: Effect of storage period and treatments on color of date candy.

were removed from syrup and dried. Syrup having $20 \%$ total soluble solids was boiled till TSS reached $40 \%$, the dates were kept in that $40 \%$ syrup for one day. This process continued till the TSS of syrup reached $70 \%$. At $70 \%$ TSS the dates were kept for about $48 \mathrm{hrs}$. At each level of TSS i.e., $0 \%, 20 \%, 40 \%, 60 \%$ and $70 \%$ the syrup was drained from dates and dried in mechanical dehydrator at $60^{\circ} \mathrm{C}$ till moisture content of $<16 \%$ is achieved. In the preparation of candy osmotic dehydration step prior to drying was used as described by Ramamurthey et al. [16]. The drying time requirement was similarly followed as described by Islam and Flink $[17,18]$.

\section{Treatments}

\section{$\mathrm{T}_{0}=$ Control}

$\mathrm{T}_{1}=$ Dates $+20 \%$ sugar syrup $+0.1 \%$ potassium metabisulphite

$\mathrm{T}_{2}=$ Dates $+40 \%$ sugar syrup $+0.1 \%$ potassium metabisulphite

$\mathrm{T}_{3}=$ Dates $+60 \%$ sugar syrup $+0.1 \%$ potassium metabisulphite
$\mathrm{T}_{4}=$ Dates $+70 \%$ sugar syrup $+0.1 \%$ potassium metabisulphite

\section{Storage}

Prepared date candy of different treatments was then wrapped in polyethylene bags and kept in cool airtight boxes for storage and further analysis.

\section{Chemical analysis}

The date candies were analyzed for moisture, $\mathrm{pH}$ and total soluble solids according the official standard method (AOAC 2003).

\section{Sensory analysis of date candy}

For statistical analysis samples were evaluated for moisture, $\mathrm{pH}$, TSS, and sensory evaluation for color, flavor, texture and overall acceptability was performed by panel of 9 members. The samples were presented to 9 members. The members were asked to rate the different composition presented to them on a 9-point hedonic scale with the ratings of: 9 = Like extremely; $8=$ Like very much; 7 = Like moderately; 6 = Like slightly; 5 = Neither like nor dislike; 4 = Dislike slightly; 3 = Dislike moderately; $2=$ Dislike very much; and $1=$ Dislike extremely. The result was analyzed by statistical software (statistics).

\section{Results and Discussion}

\section{Moisture}

The results of changes in moisture content of dhakki date candy during storage are presented in Table 1. A significant decrease was observed in moisture content during total period of storage. The moisture content decreased significantly $(\mathrm{p}<0.05)$ from 15.4 to 12.5 during total storage interval. For treatment, the highest mean was observed in T2 (14.9) while minimum was recorded in T3 (12.8).

The decrease in moisture content may be due to evaporation during storage. Variation in loss of moisture can due to variation in treatment. Chavan et al. [18] reported a decreasing trend in moisture content of osmo dried banana slices during six-month storage.

\section{pH}

The mean value of $\mathrm{pH}$ decreased from 5.63 to 4 during total period of storage. Highest mean value for treatment was observed in T1 (4.84) while the minimum value was observed in T2 (4.4) as presented in Table 2. During storage, highest percent decrease was observed in T2 (39.15) while lowest fall was recorded in T4 (20.74).

The decrease during total period of storage might be due to increase in acidity and can also be contributed to some other chemical reactions. Natalia et al. [19] also observed a decreasing trend in $\mathrm{pH}$ during storage while studying apple leather.

\section{TSS}

The mean value for TSS increased from 66.6 to 69.5 during total period of storage (Table 3 ). Highest mean value for treatment was recorded in T4 (74.2) while minimum score was recorded in T0 (47.6). Highest percent increase was recorded in T1 (5.14) while minimum increase was observed in T0 (3.11).

The increase in Total soluble solids might be due to the conversion of starch and other insoluble carbohydrates into sugar and may also be due to the loss of moisture that tends to increase TSS. A similar increasing trend was observed by Phimpharian et al. [20] reported an increase in TSS (from 82.42-86.9) while studying apple leather. 


\section{Color}

The mean score of judges for color significantly $(p<0.05)$ decreased from 8.7 to 5.2 during storage (Table 4). For treatment, maximum mean score was observed in T3 (8.0) while minimum mean score was observed in T0 (2.7).

Color of T3 was comparatively attractive during storage period at ambient temperature. Similar results have been reported by Durrani et al. [21] in development and quality evaluation of honey based carrot candy that osmotic drying had a protective effect upon the color and flavor of fully dried fruits.

\section{Flavor}

Flavor is a vital quality factor that determines the consumer attraction to the product. The results pertaining to the response of flavor on the storage interval of the candies prepared from dhakki dates are presented in Table 5 .

The mean score of judges for flavor significantly $(\mathrm{p}<0.05)$ decreased from 8.47 to 5.4 during total period of storage. For treatment, maximum mean score was observed in $\mathrm{T} 1$ (7.7) while minimum mean score was observed in T0 (1.7). These results were in harmony with the observation of Dermesonlouoglou et al. [22] who reported $54.55 \%$ decrease in flavor scores of osmo- dehydrofrozen tomatoes, during 12 months' storage.

\section{Texture}

Originally the mean score of juries for texture of date candy from

\begin{tabular}{|c|c|c|c|c|c|c|c|c|c|}
\hline \multirow[t]{2}{*}{ Treatment } & \multicolumn{7}{|c|}{ Storage Interval } & \multirow[t]{2}{*}{ \% Dec } & \multirow[t]{2}{*}{ Mean } \\
\hline & 0 & 30 & 60 & 90 & 120 & 150 & 180 & & \\
\hline T0 & 6.5 & 1.0 & 1.0 & 1.0 & 1.0 & 1.0 & 1.0 & 84.62 & $1.7 \mathrm{c}$ \\
\hline T1 & 9.0 & 8.5 & 8.0 & 7.6 & 7.3 & 7.0 & 6.5 & 27.78 & 7.7ab \\
\hline T2 & 8.8 & 8.5 & 8.1 & 7.7 & 7.2 & 7.0 & 6.8 & 22.73 & 7.6a \\
\hline T3 & 9.0 & 8.8 & 8.3 & 7.6 & 7.1 & 6.8 & 6.5 & 27.78 & 7.4ab \\
\hline T4 & 9.0 & 8.5 & 8.1 & 7.6 & 7.2 & 6.8 & 6.2 & 31.11 & $7.6 \mathrm{~b}$ \\
\hline Mean & $8.47 a$ & $7.06 b$ & $6.7 c$ & $6.3 \mathrm{~d}$ & $5.9 \mathrm{e}$ & $5.7 \mathrm{f}$ & $5.4 \mathrm{~g}$ & -- & -- \\
\hline
\end{tabular}

Table 5: Effect of storage period and treatments on flavor of date candy.

\begin{tabular}{|c|c|c|c|c|c|c|c|c|c|}
\hline \multirow{2}{*}{ Treatment } & \multicolumn{7}{|c|}{ Storage Interval } & \multirow{2}{*}{$\%$ Dec } & \multirow{2}{*}{ Mean } \\
\hline & 0 & 30 & 60 & 90 & 120 & 150 & 180 & & \\
\hline T0 & 9.0 & 2.0 & 1.0 & 1.0 & 1.0 & 1.0 & 1.0 & 88.89 & $2.2 \mathrm{e}$ \\
\hline T1 & 9.0 & 8.3 & 8.0 & 7.6 & 7.3 & 7.0 & 6.5 & 27.78 & $7.6 \mathrm{~b}$ \\
\hline T2 & 9.0 & 8.5 & 8.0 & 7.6 & 7.2 & 6.7 & 6.1 & 32.22 & $7.5 \mathrm{c}$ \\
\hline T3 & 9.0 & 8.7 & 8.3 & 8.0 & 7.6 & 7.1 & 6.7 & 25.56 & $7.9 a$ \\
\hline T4 & 9.0 & 8.3 & 8.0 & 7.4 & 7.1 & 6.5 & 6.1 & 32.22 & $7.4 d$ \\
\hline Mean & $9 a$ & $7.1 \mathrm{~b}$ & $6.6 c$ & $6.3 d$ & $6 e$ & $5.6 f$ & $5.2 \mathrm{~g}$ & -- & -- \\
\hline
\end{tabular}

Table 6: Effect of storage period and treatments on texture of date candy.

\begin{tabular}{|c|c|c|c|c|c|c|c|c|c|}
\hline \multirow{2}{*}{ Treatment } & \multicolumn{7}{|c|}{ Storage Interval } & \multirow{2}{*}{$\begin{array}{c}\% \\
\text { Dec }\end{array}$} & \multirow{2}{*}{ Mean } \\
\hline & 0 & 30 & 60 & 90 & 120 & 150 & 180 & & \\
\hline T0 & 6.0 & 2.0 & 1.0 & 1.0 & 1.0 & 1.0 & 1.0 & 83.33 & $1.8 d$ \\
\hline T1 & 9.0 & 8.5 & 8.1 & 7.7 & 7.4 & 6.6 & 6.0 & 33.33 & $7.6 \mathrm{~b}$ \\
\hline T2 & 9.0 & 8.6 & 8.1 & 7.7 & 7.3 & 6.9 & 6.6 & 26.67 & $7.7 a$ \\
\hline T3 & 9.0 & 8.6 & 8.2 & 7.8 & 7.3 & 6.9 & 6.5 & 27.78 & $7.8 a$ \\
\hline T4 & 8.8 & 8.3 & 7.9 & 7.4 & 7.1 & 6.6 & 6.1 & 30.68 & $7.4 \mathrm{c}$ \\
\hline Mean & $8.3 a$ & $7.2 b$ & $6.6 c$ & $6.3 d$ & $6 e$ & $5.6 f$ & $5.2 \mathrm{~g}$ & -- & -- \\
\hline \multicolumn{10}{|c|}{ a-g Means followed by different letters are significant $(P \leq 0.05)$} \\
\hline
\end{tabular}

Table 7: Effect of storage period and treatments on overall acceptability of date candy.
T0 0 to T4 was 9 for all, which was progressively reduced to1, 6.5, 6.1, 6.7, and 6.1 correspondingly during the total period of storage.

The mean score of judges for texture significantly $(\mathrm{p}<0.05)$ decreased from 9.00 to 5.2 during storage as presented in Table 6. For treatments, maximum mean score was observed in T3 (7.9), while minimum was recorded in T0 (2.2). The highest percent decrease was observed in T0 (88.89) while minimum was observed in T3 (25.56) Similar results were observed by Muhammad et al. [23] during storage of pear glaces.

\section{Overall acceptability}

The results on changes in overall acceptability of dhakki date candy during storage are presented in Table 7. A mean overall acceptability score of all treatments was found to gradually decrease from 8.3 to 5.2 during storage which may be due to reduction in score of color, flavor, and texture of date candy. For treatment, maximum mean score was observed in T2 and T3 both having value of 7.7 while minimum score was observed in T0 (1.8).

Chavan et al. [18] reported that a gradual decrease in overall acceptability score from 8.40 to 7.80 during six-month storage may be due to reduction in score of colour and appearance texture, taste of osmo-dried banana slices [24,25].

\section{Conclusion}

The different sugar solutions significantly affected the quality of date candy. The best quality date candy was that prepared with $60 \%$ (T3) sugar solution, followed by T2. The color, flavor and texture of date candy with $60 \%$ and $40 \%$ sugar solutions were preferred by the judges because of unique and sweat flavor. The color was excellent; taste was sweat, and a tender texture. From the results, it can be concluded that there is possibility of for utilization of surplus dates in candy making.

\section{References}

1. El-Shaarawy MI (1971) Intakes of phosphorus and calcium through excessive consumption of certain food items. In Phosphorus and Calcium Intakes by Dutch Diets. Utrecht Univ Holl.

2. Ashraf JF (2007) Antioxidant content of dates. In Proceedings of 4th Symposium on Date Palm. Al-Hassa, Saudi Arabia: 418.

3. Zohary D, Hopf M (2000) Domestication of plants in the old world: the origin and spread of cultivated plants in West Asia, Europe and the Nile valley (3rd edn) Oxford University Press, New York, USA.

4. Al-Shahib W, Marshall RJ (2003) The fruit of the date palm: Its possible use as the best food for the future. Inter J Food Sci Nutri 54: 247-259.

5. Hassan S, Bakhsh K, Gill ZA, Maqbool A, Ahmad W (2006) Economics of growing date palm in Punjab, Pakistan. Inter. J. Agri. Bio 8: 788-792.

6. Zaid A (2001) The world date production: a challenging case study. 2nd International conference on date palms, Al-Ain, UAE: 902-915.

7. FAO (2014) Food and Agriculture Organization of the United Nations. Food and agricultural commodities production for Pakistan for 2012.

8. PHDEB (2008) Pakistan Horticulture Development and Export Board. Dates Marketing Strategy.

9. Baloch AK (1999) Enhancement of post-harvest quality and stability of Dhakki dates using advanced technology. A publication of Pakistan Science Foundation, Islamabad.

10. Abul-Soad AA (2010) Date palm in Pakistan, current status and prospective. USAID Firms project: 9-11.

11. Zaid A, De Wet PF (2002) Date palm cultivation. FAO UN Plant Production and Protection.

12. Al-Hooti S, Sidhu JS, Qabazard H (1997) Physico-chemical characteristics of five date fruit cultivars grown in the United Arab Emirates. Plant Foods for Human Nutrition 50: 101-113. 
Citation: Zeeshan M, Saleem SA, Ayub M, Shah M, Jan Z (2017) Physicochemical and Sensory Evaluation of Dhakki Dates Candy. J Food Process Technol 8: 663. doi: 10.4172/2157-7110.1000663

Page 4 of 4

13. Hamad AM, Mustafa Al, Al-Kahtani MS (1983) Possibility of utilizing date syrup as a sweetening and flavoring agent in ice cream making. Proc. of the $1^{\text {st }}$ Symp. on Date Palm, King Faisl Univ Al-Hassa, Saudi Arabia, March 23-25: 544-550.

14. Khatchadourian HA, Sawaya WN, Khalil J, Safi WM, Mashadi AA (1983) Utilization of dates (Phoenix dactylifera $L$ ). grown in the Kingdom of Saudi Arabia in various date products. Proceedings of the $1^{\text {st }}$ Symposium on Date Palm, K.F. University, Al Hassa, Saudi Arabia 2: 504-518.

15. Yousif AK, Alshaawan AF, Mininah MZ, Eltaisan SM (1987) Processing of date preserve and date jelly. Date Palm J 5: 73-86.

16. Ramamurthy MS, Bongi RC, Ward R, Banoyopaifihay C (1978) Osmotic dehydration of fruits possible alternative to freeze-drying. Indian Food Pack 32: $108-112$

17. Islam MN, Flink JN (1982) Osmotic concentration and its effect on air drying behavior. Inter J Food Sci Tech. 1365-2621.

18. AOAC (2000) Official methods of analysis. (17th edn) Association of Official Analytical chemists, Arlington, VA, USA

19. Larmond E (1977) Method for sensory evaluation of food. Canada Department of Agriculture Publication.

20. Chavan UD, Prabukhanolkar AE, Pawar VD (2010) Preparation of osmotic dehydrated ripe banana slices J Food Sci and Tech 47: 380-386.

21. Natalia A, Ruiz Q, Demarchi SM, Massolo JF, Rodoni LM, et al. (2012) Evaluation of quality during storage of apple leather. LWT. Food Sci and tech 47: $485-492$

22. Phimpharin C, Jangchud A, Jangchud K, Kyoon H (2011) Physicochemical and sensory optimization of pineapple leather snack as affected by glucose syrup and pectin concentration. Inter J Food Sci and Tech 46: 972-981.

23. Durrani AM, Srivastava PK, Verma S (2011) Development and quality evaluation of honey based carrot candy. J Food Sci Tech 48: 502-505.

24. Dermesonlouoglou EK, Giannakourou M, Taoukis PS (2006) Kinetics modeling of the degradation of quality of osmo-dehydrofrozen tomatoes during storage. J Food Chem 103: 998-993.

25. Muhammad N, Shah AS, Riaz A, Hashim MM, Mahmood Z, et al. (2007) Prepration and evaluation of pear glace at different stages of maturity. Sarhad J Agric 23: 305-308. 